\title{
Communications Management in the Africa Context: Implications for Theory, Research, and Practice
}

\author{
Ronél Rensburg \\ Department of Marketing and Communication Management \\ University of Pretoria, South Africa
}

The global attempt to determine the body of knowledge for communication management has inspired and motivated African scholars and practitioners to provide insights into this field from the perspective of a developing continent. This article attempts to paint the African picture in terms of political and socioeconomic factors against the backdrop of globalization. In Africa, scholars and practitioners have an added responsibility - the utilization of communication management for development and empowerment of the continent and its people. The article investigates some implications for African communication management theory, research, and practice.

In developed countries, communication management (public relations) ${ }^{1}$ in all its contexts is of paramount importance to creating and maintaining effective relationships with all stakeholders. In Africa, in theory, this is also held as a strong argument by communication management scholars and practitioners. However, to realize this ideal in practice is much more difficult.

The issue of effective communication with stakeholders across the African continent has been noted by current South African President Thabo Mbeki. He has written and spoken often about the importance of communication, and in an open

Correspondence concerning this article should be addressed to Ronél Rensburg, Department of Marketing and Communication Management, Economics and Management Sciences Building, University of Pretoria, Lynnwood Road, 0002 Pretoria, Republic of South Africa. E-mail: ronel. rensburg@ up.ac.za

${ }^{1}$ Public relations in this context refers to communication management. The term public relations is more often recognized and used in the African context than the term communication management. Communication management will be used in the context of this article. 
letter in November 2005 he strongly stated that "communication is a fundamental human right" (Mbeki, 2005).

For readers to become aware of and comprehend the difficulties that confront communication management scholars and practitioners in Africa, a brief description of Africa's current position is necessary.

\section{THE SOCIOPOLITICAL AND ECONOMIC SCENARIO IN AFRICA}

The issues of HIV/AIDS, continuing and growing poverty, overcrowding, lack of proper housing, political conflict, rising crime levels, power shortages, lack of infrastructure, corruption - to mention but a few-are staring the developing countries of Africa in the face. In spite of the strife that accompanies many African countries and the Afro-pessimism that might abound, the mood of the African people in this ageold continent should never be underestimated. Africa has an exploding young population that is increasingly exposed to the global worldview and public sphere. It is therefore a continent where pre-modern, modern, and postmodern characteristics are present.

Scholars and practitioners should scrutinize the state of theory, research, and practice of communication management in Africa with Afro-optimism. They must determine not only how the field can make a contribution to development and empowerment in Africa, but also how Africa can contribute to the field and body of knowledge of communication management on the global stage. The African continent is a greenfield for research, and scholars have finally realized that some, but not all, aspects of the Anglo-European-American concept and practice of communication management can be transplanted onto the field in Africa. The composition of the social fabric and the value system of Africa is still far too different from that of the developed world.

On the African continent, scholars and practitioners in all spheres and disciplines must find effective ways to utilize theory, research, and practice to alleviate the pressing sociopolitical and economic problems, and also in the field of communication management. It is a responsibility and a duty, and therefore the work done in Africa must be as applied and inventive as possible. In Africa, the words of Manfred Rühl at the BledCom 2005 Symposium fully apply: "PR is what PR does" (Manfred Rühl, 2005). Public relations (as strategic communication management) is what public relations does in Africa. African scholars do not always have the luxury of metacommunication debates. Here, communication management theory, research, and practice must serve a definite purpose and must have outcomes. Against the aforementioned scenario, this article attempts to identify implications for communication management theory, research, and practice in Africa. 


\section{THE NEED FOR A PARADIGM SHIFT}

To provide implications and possible areas of research for communication management in Africa, one should be mindful of the problematic position in which social science in general finds itself in Africa. The importance of communication management as an academic discipline and as a practice might be recognized fully in Africa (particularly in South Africa, Kenya, Nigeria, and Tanzania and through the Federation of African Public Relations Associations), but there are a few obstacles to note.

Social science research in Africa has been omitted from the research agendas of the world stage for some time. The result is also the omission of the African experience from much of the world systems and other analyses where the intent is globalmainly for lack of information. The necessity, but also the problem, of doing social science research in Africa was summarized as follows by Thandika Mkandawire (1998) during the Claude Ake Lecture at the 9th General Assembly of the Council for the Development of Social Science Research in Africa held in Dakar, Senegal:

If scientific knowledge was possessed by monkeys, much of humanity would see it as "monkey business" and leave it at that. It is not that scientific and technical progress will lead humanity to nirvana or Utopia, but that it has the potential to address a large number of problems that unnecessarily haunt so much of humanity.

\section{Communication Management Research in Africa: A Tool to Improve People's Lives?}

The standing of social science in Africa can be interpreted as a function of the status of knowledge in African societies and the resources available to governments (states) for knowledge production. Africa is a region where underdevelopment prevails and poverty still characterizes the condition of the majority of people. If research is funded and executed (even communication management research), it is expected —by sponsors that fund research and by research respondents-that the outcomes of the research will improve the lives and circumstances of the majority of people. The question of how to deal with poverty and underdevelopment seems to affect perceptions of everything else and determine African research priorities (Sail, 2003, p. 11).

African researchers and scholars are attempting to make sense of increasingly complex local and global phenomena and are actively involved in the processes of development and of creating a modern public sphere, which may or may not overlap with the sphere of the state (government) or of individual communities. Social research and science in Africa is very much "a creature, if not a creation, of the states, taking their boundaries as crucial social containers" (Gulbenkian Commission, 
1996, p. 27). The development of social science teaching and research in Africa can be seen as closely linked to the birth and evolution of the post-colonial state, which can be interpreted as the modern state (Sail, 2003, p. 15). The expression of national priorities and development needs is still rife in the discourse of African scholars. They believe their role is to make sense of local, regional, national, and global social processes and transformations.

\section{Changes That Affect Communication Management Research in Africa}

The development of social research (in particular communication management) in Africa is very much a post-colonial phenomenon. But now change is affecting the social research environment. Among the different types of change that characterize the context of social science research in Africa, the following five seem to be of paramount importance (Aina, 1998; Allen, 1986; UNESCO, 1999; World Bank, 2001):

1. Economic change (from development to decline and liberalization).

2. Social change (in the status movement of large sections of elite from high to low, rapid urbanization, and an increase in mass poverty).

3. Political change (authoritarianism to the brink of despotism; liberal democratic phenomena in some countries, conflict and civil wars in others).

4. Changes in information and communication technologies (and the lack of infrastructure).

5. Changes in social institutions (expansion of certain sectors and the diversification of other institutions and governance systems).

\section{Different Communication Management Metrics for Africa?}

During the course of November 1998, the Council for the Development of Social Science Research in Africa Small Grants for Thesis Writing Selection Committee analyzed trends in the social science disciplines on the basis of 418 dossiers (Sail, 2003, p. 42). The committee found that most research studies were defined by interests that were the expression of curiosity toward daily experiences and social transformations in Africa. The themes that were based on the realities of the day mirrored the pluralism and dynamism of the emerging social science research community. These were attempts to adapt the disciplines to local African conditions not merely through the study of local phenomena, but also by attempting to revisit certain theories and research methodologies. Scholars all over Africa are looking to indigenize disciplines (Niang, 2000). As an indigenized discipline, communication management could, for example, study the following: 
1. African communication themes or issues of particular interest to Africa.

2. Conceptual frameworks and research paradigms in communication management developed by African scholars.

3. Particular African innovations in communication management research methodologies, such as settlu, a traditional method of observation that does not disturb the observed. It is common knowledge that Western-based metrics like interviews and questionnaires are not always effective in collecting data in Africa for numerous reasons (from low literacy levels to cultural taboos). For example, in many African societies, the question-and-answer format is problematic, as African respondents prefer to draw the interviewer into a dialogue (Sail, 2003). The methodology to be developed here will then take such a relationship between the interviewer and respondent into account (cf. Niang, 2000, for a discussion regarding problems associated with data collection by questionnaire in African communities).

The parochial nature of the research is in the choice of research topics, themes, and tools. As far as research methods being used are concerned, communication management and general communication science as practiced in Africa are as universal as they are anywhere else in the world. Moreover, as scholars like Mamdani (2001) have argued, African scholars have always studied Africa in the world. The tendency to select topics close to the continent is probably part of a more global postmodern shift away from grand theory and grand systems. However, certain topics (as is the case with communication management) can be universally convergent in nature.

\section{Communication Management Research in Africa: Implications}

Is there a need for a complete communication management paradigm shift for Africa then? According to Kuhn, paradigms are "general ways of seeing the world"(cf. Kuhn, 1970). Paradigms determine "normal science" (cf. Kuhn, 1970) and therefore also the kind of analysis that is made of a given social phenomenon. A paradigm shift occurs when, as a result of the evolution of social phenomena and/or developments within science itself, new general ways of seeing the world emerge (Abercrombie, Hill, \& Turner, 1994; Kuhn, 1970). However, a real empirical base for social research remains.

Given the dominant paradigm and given its close connections with post-independence development processes, social science research in Africa was primarily intended to serve state and national development purposes, themselves conceived in very state-like terms. The state was therefore not only the key theme in social science, but also the main user of the research executed. Now the research has already become more diversified to include business, social movements, civil society organizations, and so on. Among the key topics for research that emerge in debates surrounding both theories and paradigms in communication management in Africa 
are the following: personal and cultural identity, Africanity, ethnic identities and ethnicity, and race; Africa in the world economy; social movements; activism; structural adjustments; gender issues; authoritarianism; challenges in democratic transitions; corporate governance and citizenship; conflict and conflict resolution; rural and agrarian issues; business incubation; small and medium enterprises; Black empowerment; urban processes; regional integration; endogenous knowledge and research-based global knowledge; reputation management; corruption, and HIV/AIDS. Globalization has also become a dominant issue in research debates in Africa. Policy options such as de-linking in the context of globalization are no longer debated. Instead the question is frequently posed whether Africa should seek to achieve restricted integration into the world economy (Mkandawire \& Soludo, 1999). Africa needs to be able to compete in the global market of goods, ideas, services, and influences from a much less disadvantaged position.

Among the most important constraints faced by the African research community are the extremely volatile political environment and the very precarious economic and social conditions in which it has to operate. The rapid changes now also pose considerable challenges for institutions and scholars alike, and the challenges facing communities are many and varied. Social reality in Africa is becoming increasingly complex. Keeping up with the academic debates globally in the respective disciplines (also in communication management) is a major challenge for African scholars. The drive toward marketability is also a global phenomenon that brings to light major questions about agenda setting for research carried out on the African continent. The information technology revolution in particular brings along its own cohort of opportunities and risks for Africa. According to the Senegalese philosopher Bachir Diagne (2001), the Internet, for many African scholars, "just enables us to know what we don't have." More effort also ought to go into establishing new African communication management models and theories based upon a true African philosophy.

\section{COMMUNICATION MANAGEMENT AND THE PERSUASIVE SCIENCES IN AFRICA}

The strategic use of communication management is an increasingly important part of the communication and media environment in contemporary society. It has spread throughout the world, from developed industrial economies to developing states and societies. Wherever global capitalism and liberal democracy are to be found, it is likely that communication management will also be there. But in Africa, not all stakeholders and manufacturers of communication are fully informed of the degrees of difference between communication management and other persuasive sciences. 


\section{Communication Management and Propaganda}

In those states in Africa where there are still totalitarian regimes, communication management is often still mistaken for, or even referred to, as propaganda. This is seen - by scholars in developed countries-as a challenge for communication management scholars in Africa. However, the distinction between communication management and propaganda in Africa is not always easy to discern. Terrorism and propaganda are closely and visibly linked in the post-9/11 era, the War on Terror campaigns, and so forth. Some critics have argued that the term propaganda should be used in a nonpejorative or neutral sense. One widely cited definition states: "Propaganda is the deliberate and systematic attempt to shape perceptions, manipulate cognitions, and direct behavior to achieve a response that furthers the desired intent of the propagandist" (Jowett \& O'Donnell, 1992, p. 4). Many authors, especially those writing about communication management, contrast the manipulative intent of the propagandist with the free and open exchange of ideas that characterizes communication management in developed liberal democracies. For example, from an American perspective it is argued that communication management is underpinned by the First Amendment in the United States Constitution, and that freedom of speech is in the long run the greatest deterrent to the misuse of propaganda. It follows that a society without propaganda would be one with no serious divisions of interest. In such a Utopia, disputes would be adjudicated by free, fair, and, above all, rational debate. In the African environment, however, things are not so simple.

The central problem with attempts at workable definitions of propaganda is that the question of who is the propagandist is always contested. The identification of a propagandist in the real world is a matter of political argument that is linked to specific interests and ideologies. It is perhaps more adequate and instructive to see propaganda as a "matter of the politics of information" (Robins, Webster, \& Pickering, 1987, p. 8). Nevertheless, propaganda is often only a small part of the media and information strategies of Western governments, but a large part of the strategies of African governments. It can be argued that propaganda is a form of information strategy that does not differ in any meaningful sense from the contemporary practice of communication management, though the vast majority of those working in communication management would reject this comparison. Indeed, propaganda is usually composed largely of truthful information.

Let me now address the government's duty to communicate. And I use the broader concept of "communicate," not the narrow one of "inform." For, important as the duty to inform is, it is much more important to communicate, creating space for dialogue, and generally conducing to a free flow of thoughts and ideas. Communication, rather than information, builds stronger institutions and processes for good governance. It is about improving interaction between government and the governed, in whose name decisions are made, tax money spent. (Mkapa, 2003) 
In the past decade, Tanzania has embarked on economic, political, and legal reforms aimed at fostering development. As such, the government has introduced a number of initiatives to enhance accountability, integrity, and transparency in public affairs. In 2003, the then-president of Tanzania, Benjamin W. Mkapa, established a Directorate of Communication within the State House. The directorate was established to gradually assist in building up capacity throughout the government for better, more effective, and more coordinated public communication with various stakeholders. On March 18-20, 2003, the directorate organized a workshop that brought together permanent secretaries from government ministries, diplomats, top media executives, and selected communication practitioners to deliberate on ways of improving public communication and relations between the media and the government. Two key recommendations evolved from the workshop: (a) that the government should amend restrictive laws, improve transparency, and create channels for effective and efficient two-way communication between it and its stakeholders; and (b) that there should be training for media personnel in areas of specialized reporting and ethics, as well as broadened dialogue between media personnel and government officials for the benefit of the public.

In South Africa, the Government Communication and Information System has echoed similar sentiments. It has been in existence in its current form for a few years now. Its vision is helping to meet the communication and information needs of the South African government and people and to ensure a better life for all. Its mission is to provide leadership in government communication and ensure that the public is informed of the government's implementation of its mandate. The overarching strategic objective of the Government Communication and Information System is to enhance the government communication system and its operations in ways that contribute to the process of further consolidating South Africa's democracy and taking the country into a higher growth sphere.

\section{Communication Management and Government Communication in Africa: Implications for Theory, Research, and Practice}

Government communication is important in Africa, and therefore it is pivotal that governments, politicians, the media, communication scholars, and communication management practitioners work in unison to arrive at shared communication practices in this sector. If the theory, research, and practice implications are considered, there are many possibilities for strategic communication management in Africa. These are, among others: preparing government communication guidelines and putting in place an effective government communication strategy, setting up media monitoring units, providing better leadership (through continuous training) in government communication, and continuously improving communication research and 
government information quality control. Government communication systems across Africa need to

- base their strategies and operations on sound research through cooperation with research institutions and universities;

- develop closer relations with agenda setters by building partnerships with the media, activist groups, and business;

- sustain profiling of the benefits of African development for South Africa and the rest of the continent;

- improve government communication structures, preparing communication strategies for the New Partnership for Africa's Development and the African Union;

- work toward an international marketing campaign for the African continent, such as the Branding South Africa project;

- improve government lekgotla and imbizo communication (workshops and group retreats in the African context);

- utilize communication management more strategically to combat HIV/ AIDS; and

- curtail crime and corruption on the continent.

Areas where communication management could further be used substantially are in the promotion of intercultural and development communication, and social cohesion and nation building. There are already campaigns and programs regarding these in place, like the Batho Pele or People First campaign in the South African Public Service and the effective anti-HIV/AIDS program in Uganda. The role of communication management (as diplomatic communication) in enhancing Africa's foreign and international relations as a player on the global stage should be investigated and exploited more thoroughly in future.

\section{COMMUNICATION MANAGEMENT, TRANSFORMATION, AND REPUTATION MANAGEMENT IN AFRICA}

Cultural diversity and complexity is a challenge but also an opportunity. With a more Africanized workforce, transformation and change research carried out in South Africa points to the need for a move toward Afrocentric approaches to training and development and to move organizations toward a core African-based value system (Bradfield, 2004, June 22). However, the need to grow and develop people must be balanced with the imperative to be globally competitive through a distinctive productivity and profit focus. Yet management styles in African organizations are often seen as rigid, bureaucratic, directive, and task oriented, with over-centralized decision making. Leadership aspects such as direction, vision, and effectiveness are 
found wanting. The present environment is in stark contrast to the influence of the democratic process, which requires organizations to look toward more involvement of their employees in decision making and to be more consultative and participative. As organizations increasingly reflect external demographics with a greater intake of previously disadvantaged groups, communicators and practitioners will possibly be presented with rich possibilities for communication.

With changes in the managerial system in organizations in Africa, the supporting communication subsystem may well be influenced with a communication structure that is more open and responsive; creates more tolerance, trust, and respect in the work environment; and is more tuned in to the needs of, among others, the female market. A more informed and motivated workforce has benefits for increased efficiency and productivity.

\section{Corporate Reputation Management in South Africa: Implications for Theory, Research, and Practice}

Recent corporate scandals across the world have illustrated how easy it is for established brands and organizations to evaporate from the corporate world stage. The same rings true for a country and its reputation.

The quiet diplomacy of South Africa toward the ills in Zimbabwe; appalling parastatal communication management during the recent strikes at South African Airways and the supermarket chain Pick 'n Pay; municipal worker strikes; shaky explanations about power shortages across South Africa; and alarming crime statistics all have the potential to damage not only the affected organizations' corporate reputations, but the reputation of the country. In 2010 the Soccer World Cup comes to South Africa. South Africa cannot afford the lack of discipline that accompanies strikes, industrial action, and crime. South Africa needs foreign investment to create jobs and to grow entrepreneurs and small businesses. It cannot perpetuate the accumulation of unsavory perceptions of the country. Before embarking on these actions, those involved should consider how their behavior could impact on South Africa's reputation and how strategic communication can be employed in these endeavors. Communication management can play a role here and should be utilized more appropriately and strategically.

When considering organizations operating in Africa, communication management practitioners wishing to promote the importance of strategic communication have to push extra hard to make their presence felt. In numerous African organizations, communication must be "sold" to the chief executive officer. Key executive issues that communication management practitioners must be aware of include strategic, political (internal and external), financial, and cultural issues, including competitiveness, communication, cooperation, and consensus. If communication 
practitioners, consultants, and managers can illustrate to senior executives how their solutions can solve business problems, they will stand a much better chance of selling their communication programs to the top business decision makers (Bradfield, 2004, October 14).

When it comes to influencing the captains of industry, African communication managers and practitioners cannot compromise on preparation, strategic business literacy, ${ }^{4}$ and linking their communication inputs to executive issues. Workplace change and transformation, almost constant these days, contribute largely to conflicts in African organizations. A definite challenge for communication management practice is the education of senior executives who clearly do not have an idea of what strategic communication is all about; therefore, yet another key performance area is added to the job description of African communication management practitioners.

\section{CONCLUSIONS}

This article has merely scraped the surface of possibilities and implications for strategic communication theory, research, and practice in Africa. However, the expectation is that it has emphasized some issues that scholars and practitioners should be mindful of in the African context.

The role of communication management in contemporary society is intimately linked with the economy and the sociopolitical environment in Africa. To understand the nature of governance, one can look at the way that successful and powerful business and political leaders communicate with their stakeholders in Africa. Communication management is central to this process, but it is also more-it engages the stakeholders.

In forming a pivotal link in the chain of marketing, promoting, and branding Africa, communication management needs to balance the realities and the perceptions of the continent with cohesive and consistent messages. Stakeholders should be engaged to work together in popularizing the vision of a shared destiny for country, region, and continent, while linking national and regional interest to mutual development and global participation. Here communication management will be the voice of African visibility as an interdisciplinary phenomenon.

There is a dire need to establish communication management in Africa-not as a soft skill, but as a hard skill, a solid competency that business and governments should not compromise on. In Africa, the emphasis should not be solely on communication management (practitioners dealing with communication complexities) but also on communication leadership (practitioners operating as communication visionaries).

\footnotetext{
${ }^{4}$ Communication managers and practitioners should be familiar with the world of business as a whole and not only skilled in their particular specialization and functional areas of communication.
} 
With the assistance of communication management theory, research, and practice as such, South Africa and the rest of the African continent might realize the dream of becoming alive with possibilities.

\section{REFERENCES}

Abercrombie,N. S., Hill, S.,\& Turner, B. (1994). Dictionary of sociology (3rd ed.). London: Penguin.

Aina, T. (1998). The state of social sciences in contemporary sub-Saharan Africa: A status report. Mimeo. N.p.

Allen, C. H. (1986, June). A review of social science research in Eastern, Southern and some West African slates. Report to SAREC. Stockholm, Sweden: SAREC.

Bradfield, J. (2004, June 22). Opportunities for communication through diversity. Bizcommunity.com. Retrieved June 22,2004, from http://www.bizcommunity.com/Article.aspx?c=l l\&l=196\&ai=3909

Bradfield, J. (2004, October 14). Selling communication to the CEO. Dizcommitnity.com. Retrieved October 14, 2004, from http://www.bizcornmunity.com/Article.aspx7cH 8\&l=196\&ai=4884

Diagne, B. (2001). Africanity as an open question. In Identity and beyond: Rethinking Africanity. Uppsala, Sweden: Nordiska Afrikainstitut.

Gulbenkian Commission on the Restructuring of the Social Sciences. (1996). Open the social sciences: Report of the Gulbenkian Commission of the Restructuring on the Social Sciences. Stanford, CA: Stanford University Press.

Jowett, G., \& O'Donnell, V. (1992). Propaganda and persuasion. London: Sage.

Kuhn, T. S. (1970). The structure of scientific revolution (2nd ed.). Chicago: University of Chicago Press.

Mamdani, A. (2001). Understanding the crisis in Kivu. Dakar, Senegal: Council for the Development of Social Science Research in Africa.

Mbeki, T. (2005). Letter from the president. ANC Today, 5(44), 4-10.

McNair, B. (1995). An introduction to political communication. London: Routledge.

Mkandawire, T. (1998, December). The social sciences and democracy: Debates in Africa. Lecture delivered at the 9th General Assembly of the Council for the Development of Social Science Research in Africa, Dakar, Senegal.

Mkandawire, T., \& Soludo, C. (1999). Our continent, our future: African perspectives on structural adjustment. Dakar, Senegal: Council for the Development of Social Science Research in Africa, International Development Research Centre, Africa World Press.

Mkapa, B. W. (2003, March). Presentation at the opening of a workshop on government communication, Dar-es-Salaam, Tanzania.

Niang, A. (2000). "Settlu," technique traditionelle d'observation. Mimeo. Saint-Louis: Universite Gaston Berger.

Robins, K., Webster, R, \& Pickering, M. (1987). Propaganda, inference and social context. In J. Hawthorne (Ed.), Propaganda, persuasion and polemic. London: Edward Arnold.

Sail, E. (2003). The social sciences in Africa: Trends, issues, capacities and constraints. New York: Social Science Research Council.

Sole, S., \& Brümmer, S. (2006, January 20-26). The gravy plane. The unanswered questions and air farce. Mail \& Guardian, p. 4.

UNESCO. (1999). World social science report. Paris, France: Author.

World Bank. (2001). Constructing knowledge societies: New challenges for tertiary education. A World Bank strategy. Washington, DC: Author. 